\title{
Biological and Molecular Characterization of a Novel Tobamovirus with a Unique Host Range
}

Scott Adkins and Ivanka Kamenova, U.S. Department of Agriculture, Agricultural Research Service, U.S. Horticultural Research Laboratory, 2001 South Rock Road, Fort Pierce, FL 34945; and Diann Achor, Citrus Research and Education Center, and Dennis J. Lewandowski, Department of Plant Pathology, University of Florida, 700 Experiment Station Road, Lake Alfred 33850

\begin{abstract}
Adkins, S., Kamenova, I., Achor, D., and Lewandowski, D. J. 2003. Biological and molecular characterization of a novel tobamovirus with a unique host range. Plant Dis. 87:1190-1196.

Tobamoviruses are among the best characterized and most studied plant viruses. Three subgroups of tobamoviruses correspond to viral genome sequence and host range to include those viruses infecting (i) solanaceous plants, (ii) brassicas, or (iii) cucurbits or legumes. We isolated a virus from Florida landscape plantings of the malvaceous plant hibiscus (Hibiscus rosasinensis) that appears to be a tobamovirus based upon its virion morphology, genome organization, and coat protein sequence. The experimental host range of this virus included five malvaceous species but excluded all tested brassica, cucurbit, and legume species and 12 of the 19 solanaceous species tested. The unique host range and comparison of coat protein gene and protein sequences with those of recognized tobamoviruses indicate that this is a novel tobamovirus. A limited survey revealed that this virus is widespread in hibiscus and related species in the Florida landscape.
\end{abstract}

The discovery of Tobacco mosaic virus (TMV) in the late 1800 s is generally considered to herald the beginning of the science of virology (28). The early detection and ease of experimental manipulation of the tobamoviruses have made them some of the most intensively studied of all viruses (13). Phylogenetic analysis of recognized and tentative tobamovirus species has revealed three subgroups within the genus, which correspond well with groupings established using host range $(3,11,16,26,38)$. These three tobamovirus subgroups are those that infect (i) solanaceous plants, (ii) brassicas, and (iii) cucurbits or legumes. Coevolution of tobamoviruses with their hosts is a current theory for the correspondence of groupings based upon virus sequences with those based upon host range $(11,16)$.

Hibiscus (Hibiscus rosa-sinensis) is a malvaceous plant common in the landscape in the southern United States and popular as an indoor/outdoor potted plant in the northern United States. Vegetative propagation of stock plants in the southern United States generates rooted cuttings that are shipped north for indoor use during

Corresponding author: Scott Adkins

E-mail: SAdkins@ushrl.ars.usda.gov

Accepted for publication 14 May 2003.

Publication no. D-2003-0711-01R

This article is in the public domain and not copyrightable. It may be freely reprinted with customary crediting of the source. The American Phytopathological Society, 2003. winter months and outdoor use during summer months (17). Vegetative propagation makes the transmission of viruses from stock plants to cuttings a potentially serious problem. Producers of many vegetatively propagated ornamentals index their stock plants to decrease the likelihood of propagating infected plants (24).

Three well-characterized viruses infect hibiscus: Hibiscus chlorotic ringspot virus (HCRSV), Hibiscus latent ringspot virus (HLRSV), and Tomato vein-yellowing virus (TVYV; also known as Eggplant mottled dwarf virus) (17). The entire genome of HCRSV has recently been sequenced (12). Virions of HCRSV and HLRSV are spherical; whereas virions of TVYV are bullet-shaped $(17,21)$. Several partially characterized viruses have also been reported to infect hibiscus or closely related species $(15,17,37)$. A single, brief report describes a putative tobamovirus infecting hibiscus in Japan (14), although no subsequent reports have been found. There is insufficient data in the literature to determine if these viruses are related to the three well-characterized hibiscus-infecting viruses described above or to the virus we have isolated from hibiscus in Florida and reported here. During the preparation of this manuscript, a report was made of a (HVS), infecting hibiscus in Singapore (29); however, indicator host symptoms and coat protein $(\mathrm{CP})$ sequence data indicate that the Florida hibiscus virus is distinct from this virus.

In this paper, we present biological and molecular characterization of the Florida putative tobamovirus, Hibiscus virus $\mathrm{S}$ hibiscus virus. The unique host range of this virus, coupled with analysis of the deduced CP gene, suggest that it is a novel tobamovirus and distinct from the recently described HVS.

\section{MATERIALS AND METHODS}

Virus sources and maintenance. Foliar symptoms suggestive of virus infection, including diffuse chlorotic spots and rings and an overall chlorotic mottle (Fig. 1A and B), were observed in hibiscus landscape plantings in southeast Florida. The putative tobamovirus characterized in this report was initially transmitted mechanically to Chenopodium quinoa from symptomatic hibiscus leaves homogenized in $20 \mathrm{mM}$ sodium phosphate buffer $(\mathrm{pH} 7.0)$ containing $1 \%$ (wt/vol) Celite. Successive mechanical passages in $C$. quinoa were used to maintain and increase the virus due to the difficulty of working directly with hibiscus tissue. TMV strain U1 and a Florida isolate of Pepper mild mottle virus (PMMoV; 1) were maintained by the same method in Nicotiana tabacum cv. Xanthi.

Isolation and characterization of double-stranded (ds) RNA and virions. DsRNA was extracted from 7-g samples of inoculated $C$. quinoa leaf tissue following a protocol previously published (34) except that a single cycle of cellulose chromatography was used. DsRNA was analyzed by electrophoresis on native $5 \%$ polyacrylamide gels and detected by silver staining using a commercially available kit (BioRad, Hercules, CA).

Virions were isolated from inoculated leaves of $C$. quinoa (Florida hibiscus virus) or upper, uninoculated leaves of $N$. tabacum cv. Xanthi (TMV and PMMoV) essentially as described by Wetter and Conti (36). Extinction coefficients of $E_{260 \mathrm{~nm}^{0.1 \%}}=3.00$ (Florida hibiscus virus and TMV) and $E_{260 \mathrm{~nm}}{ }^{0.1 \%}=3.18(\mathrm{PMMoV})$ were used to estimate virus concentration spectrophotometrically (36).

Leaf dips of hibiscus and $C$. quinoa leaves were made on 200 mesh Formvarcoated copper grids and stained with 5\% (wt/vol) uranyl acetate. Virion preparations were analyzed in the same manner. Measurements of 200 particles representative of the Florida hibiscus virus (20 particles per each of 10 micrographs) were used to determine a mean particle length. 
Host range determination. An experimental host range for the Florida hibiscus virus was determined by mechanically inoculating 45 species in 16 families with the virion preparation. All experimental hosts were grown from seed except for Turk's cap, which was propagated by cuttings from a symptomless, nursery-grown plant, and hibiscus, which was kindly provided as culture virus-indexed cuttings by Brad Reddick and Nancy Rechcigl (Yoder Brothers, Inc., Alva, FL). All Brassicaceae were maintained at $20^{\circ} \mathrm{C}$ in a growth chamber (16 h light/ $8 \mathrm{~h}$ dark), and all other plants were maintained in an airconditioned greenhouse under natural lighting with a daytime high temperature of $30^{\circ} \mathrm{C}$. All plants were mechanically inoculated with virions in the phosphate buffer indicated above at the three- to fiveleaf stage. Plants were evaluated weekly for symptoms. To confirm systemic infection, upper, uninoculated leaves were homogenized in phosphate buffer and used to inoculate $C$. quinoa. To confirm local infection in a few species, washed, inoculated leaves were homogenized in phosphate buffer and used to inoculate $C$. quinoa. Two weeks later, inoculated leaves of $C$. quinoa were examined for chlorotic local lesions.

Production of polyclonal antiserum. A male New Zealand white rabbit was injected once, subcutaneously, with virions $(100 \mu \mathrm{g})$ mixed with an equal volume of Complete Freund's Adjuvant at Cocalico Biologicals, Inc. (Reamstown, PA). Booster injections of virions $(50 \mu \mathrm{g})$ mixed with an equal volume of Incomplete Freund's Adjuvant were made subcutaneously and intramuscularly at 2, 3, 7, and 11 weeks after the initial injection. Production bleeds were started a week after the last booster injection. IgG was purified from the rabbit serum by ammonium sulfate precipitation as previously described (7) and stored with $0.5 \%(\mathrm{wt} / \mathrm{vol})$ sodium azide at $4^{\circ} \mathrm{C}$.

Protein analysis. Virions (Florida hibiscus virus, PMMoV, and TMV) were analyzed by sodium dodecyl sulfate- polyacrylamide gel electrophoresis (SDSPAGE) on $15 \%$ SDS-PAGE gels and stained with Coomassie brilliant blue G250 according to established protocols (27). For serological analysis, proteins in replicate gels were transferred following electrophoresis to polyvinylidene difluoride membranes as described previously (32). A working concentration of 333 ng of purified IgG per ml against the Florida hibiscus virus was used for detection of viral antigens; a 1:3,000 dilution ( $\mathrm{vol} / \mathrm{vol})$ of commercially available goat anti-rabbit IgG conjugated to alkaline phosphatase (Bio-Rad) was used for detection of the primary antibody with nitro blue tetrazolium and 5-bromo-4-chloro-3-indolyl phosphate for substrate as described previously (32), except that 5\% nonfat dried milk (wt/vol) was used in place of gelatin.

Cloning and analysis of the CP gene. Viral genomic RNA was extracted from virions according to previously described methods (22). First strand cDNA was synthesized by Moloney murine leukemia virus reverse transcriptase (Promega, Madison, WI) at $50^{\circ} \mathrm{C}$ for $45 \mathrm{~min}$ with standard methods (27). One population of clones was prepared by priming first-strand cDNA synthesis with a degenerate tobamovirus $3^{\prime}$ end primer (5'-TGGGCCSCWACCSGSGGT-3'). This was followed by 30 cycles of polymerase chain reaction amplification with Vent polymerase (New England Biolabs, Beverly, MA) at $94^{\circ} \mathrm{C}$ for $1 \mathrm{~min}, 49^{\circ} \mathrm{C}$ for $45 \mathrm{~s}$, and $72^{\circ} \mathrm{C}$ for $45 \mathrm{~s}$ using the above primer and a second degenerate tobamovirus primer (5'GAYWCHMGDAAYAGRRYHHATHGA$3^{\prime}$ ) located within the CP gene. A second population of clones was prepared by priming first-strand cDNA synthesis with random hexamers. Second-strand cDNA was synthesized with the Klenow fragment of DNA Polymerase I. Products from both types of cDNA synthesis reactions were phosphorylated with T4 polynucleotide kinase and ligated into the EcoRV site of pGEM-5Zf (Promega).

Selected clones were sequenced on an $\mathrm{ABI} 3700$ automated sequencer at the
USHRL Genomics Laboratory. Sequences were edited in VectorNTI (InforMax, North Bethesda, MD) and subjected to BLAST searches (2). The only sequences producing significant alignments from BLASTX queries were the CPs of recognized tobamoviruses. Overlapping clones were aligned manually and with Clustal $\mathrm{X}$ version 1.8 (30) to assemble the complete Florida hibiscus virus $\mathrm{CP}$ gene.

Multiple alignments of the $\mathrm{CP}$ genes and deduced proteins of Florida hibiscus virus, HVS, and each recognized tobamovirus species were prepared using Clustal W version 1.82 (31) using Tobacco rattle virus as the outgroup. Percent nucleotide and amino acid identities were calculated using GeneDoc (23). Neighbor-joining trees were generated with PHYLIP version $3.6 \mathrm{a} 3$ (10) programs DNADIST (CP gene) or PROTDIST (CP) and NEIGHBOR. A tree based on maximum parsimony was similarly generated for CPs using the PROTDIST and PROTPARS programs of PHYLIP. The resulting trees were displayed in TreeView (25). The significance of the branching order was assessed by bootstrap resampling of 1,000 replicates using the SEQBOOT program of PHYLIP.

RNA analysis. Protoplasts from a tobacco suspension cell line were inoculated with virion RNA as previously described (20). To determine if the Florida hibiscus virus replicated in tobacco protoplasts, total RNA was extracted at $\sim 22 \mathrm{~h}$ postinoculation and analyzed by northern blot hybridization as previously described (19). Positive-strand RNA was detected with a digoxigenin-labeled (Roche Molecular Biochemicals, Indianapolis, IN) riboprobe transcribed from the Sp6 promoter of the pGEM5Zf vector containing an internal portion of the $\mathrm{CP}$ gene.

Double antibody sandwich enzymelinked immunosorbent assay (DASELISA). Purified $\mathrm{IgG}$ at $1 \mathrm{mg} / \mathrm{ml}$ was conjugated with alkaline phosphatase (Roche Molecular Biochemicals) according to Avrameas (4). Conjugate was stored with $1 \%(\mathrm{wt} / \mathrm{vol})$ bovine serum albumin and $0.5 \%(\mathrm{wt} / \mathrm{vol})$ sodium azide at $4{ }^{\circ} \mathrm{C}$. A
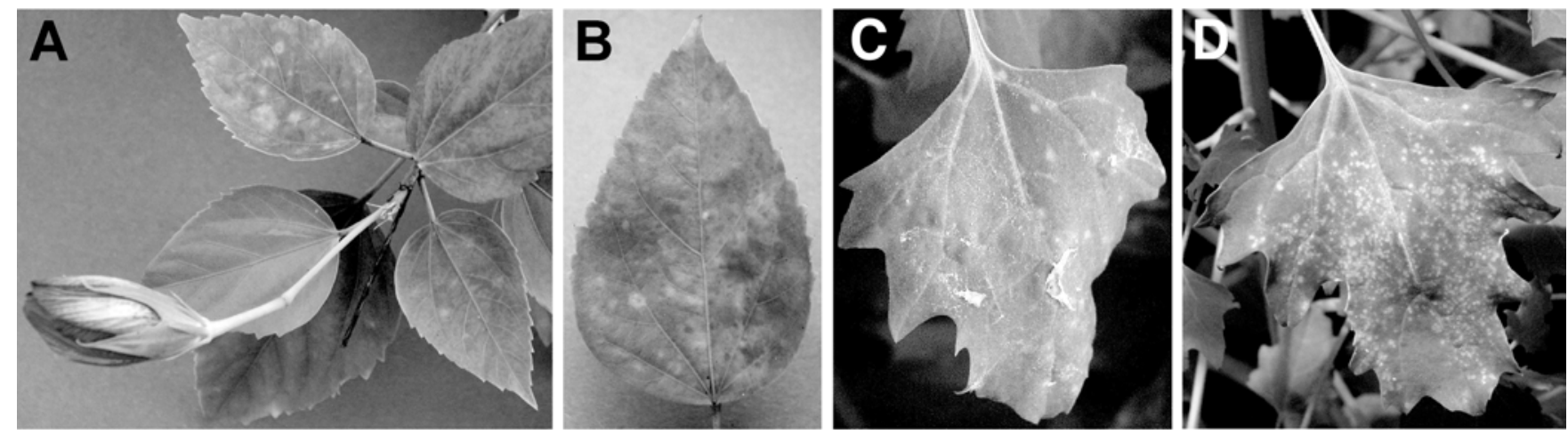

Fig. 1. Mechanical transmission of the putative hibiscus tobamovirus from hibiscus to Chenopodium quinoa. A, Typical viruslike symptoms observed in Florida landscape plantings of hibiscus (Hibiscus rosa-sinensis) include diffuse chlorotic spots and rings and $\mathbf{B}$, an overall chlorotic mottle. $\mathbf{C}$, Initial mechanical transmission from hibiscus leaves to C. quinoa resulted in the formation of a few chlorotic local lesions. Note residue of hibiscus sap on leaf. D, Subsequent mechanical transmission from pooled local lesions in $(\mathbf{C})$ resulted in the formation of hundreds of local lesions on another $C$. quinoa leaf. 
DAS-ELISA protocol was developed for detection of the Florida hibiscus virus directly from hibiscus leaves following published methods (7). Briefly, polystyrene microtiter plates were coated with $\mathrm{IgG}$ (100 $\mu \mathrm{l}$ of $1 \mu \mathrm{g} / \mathrm{ml}$ per well) diluted in 0.05 $\mathrm{M}$ sodium carbonate $(\mathrm{pH}$ 9.6). Leaf tissue was homogenized in phosphate-buffered saline (PBS; $0.14 \mathrm{M} \mathrm{NaCl}, 1 \mathrm{mM} \mathrm{KH} \mathrm{PO}_{4}$, $8 \mathrm{mM} \mathrm{Na} \mathrm{HPO}_{4}, 2.5 \mathrm{mM} \mathrm{KCl}$ [pH 7.4]) containing $0.5 \%$ (vol/vol) Tween $20,2 \%$ (wt/vol) polyvinylpyrrolidone, and $0.2 \%$ (wt/vol) ovalbumin (sample buffer). Homogenate $(100 \mu \mathrm{l}$ per well) was added to the plate and incubated overnight at $4^{\circ} \mathrm{C}$. Plates were washed three times with PBS containing $0.5 \%$ (wt/vol) Tween 20. Conjugated $\operatorname{IgG}(1: 1,000$ dilution in sample buffer, $100 \mu \mathrm{l}$ per well) was added to the plate and incubated $3 \mathrm{~h}$ at $37^{\circ} \mathrm{C}$. Plates were washed as above, $p$-nitrophenyl phosphate was added, and $405 \mathrm{~nm}$ absorbance $\left(A_{405 \mathrm{~nm}}\right)$ readings were measured after a 2-h room temperature incubation. Controls of sample buffer only, uninfected leaves, and infected leaves were included in all assays. Four wells were used for each sample with the mean becoming the $A_{405} \mathrm{~nm}$ reading for the sample. Samples with $A_{405} \mathrm{~nm}$ readings $>0.1$ were considered positive, a reading which was always a minimum of four to five times the mean absorbance of uninfected leaves. Hibiscus samples were collected during travels in peninsular Florida by members of our laboratories and assayed to develop an initial geographic distribution of the Florida hibiscus virus.

\section{RESULTS}

Isolation of Florida hibiscus virus. An agent was mechanically transmitted from symptomatic hibiscus leaves (Fig. 1A and $\mathrm{B})$ to $C$. quinoa as determined by the development of a few chlorotic local lesions (Fig. 1C). Subsequent mechanical passages in C. quinoa led to the formation of hundreds of chlorotic local lesions per leaf (Fig. 1D). Electron microscopy of leaf dips prepared from symptomatic hibiscus leaves revealed rod-shaped particles (data not shown) consistent with those of a tobamovirus. A dsRNA that co-migrated with a TMV dsRNA marker was isolated from inoculated $C$. quinoa leaves (Fig. 2A), suggesting that the agent might be a tobamovirus. Thus, a typical tobamovirus virion isolation protocol (36) was attempted from symptomatic $C$. quinoa leaves. Electron microscopy of the resulting preparation revealed rod-shaped particles (mean length of $295 \mathrm{~nm}$; Fig. 2B) that were indistinguishable from those observed in the leaf dips and typical of those described for tobamoviruses.

Host range determination. An experimental host range for the Florida hibiscus virus was determined by mechanical inoculation of 45 species (Table 1), including hosts reported for members of each of the three subgroups of tobamoviruses. No evidence of infection was detected in any of the tested brassica (Brassicaceae), cucurbit (Cucurbitaceae), or legume (Fabaceae) species. Symptoms were produced on inoculated leaves of three species in the Solanaceae (Nicotiana glutinosa, N. rustica, and Petunia $\times$ hybrida). A fourth solanaceous plant ( $N$. benthamiana) was a symptomless, systemic host, and three other solanaceous plants ( $N$. debneyi, $N$. excelsior, and $N$. occidentalis) were symptomless, local hosts. Three other species
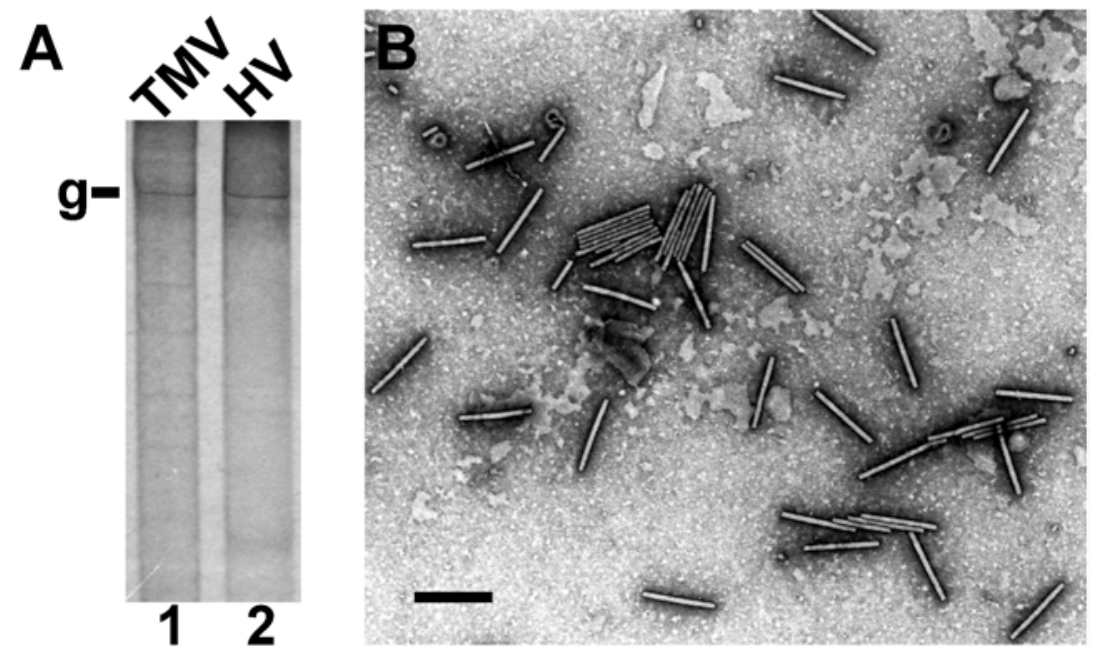

Fig. 2. Results of Florida hibiscus virus (HV) characterization by viral-associated double-stranded (ds) RNA analysis and electron microscopy are consistent with it being a tobamovirus. A, HV dsRNA co-migrates with Tobacco mosaic virus (TMV) dsRNA. DsRNA was isolated from inoculated, symptomatic leaves of Chenopodium quinoa (Fig. 1D), analyzed by native electrophoresis on a $5 \%$ polyacrylamide gel, and stained with silver (lane 2). TMV dsRNA isolated from Nicotiana tabacum cv. Xanthi was used as a reference (lane 1) with the position of the TMV genomic (g) dsRNA indicated to the left of the gel. B, Virion morphology is typical of recognized tobamoviruses. Virion preparation resulting from a typical tobamovirus isolation protocol (36) stained with 5\% (wt/vol) uranyl acetate and analyzed by electron microscopy. Mean particle length of two hundred measured virions was $295 \mathrm{~nm}$. Scale bar represents $300 \mathrm{~nm}$. commonly used as indicator hosts for tobamoviruses were susceptible: Gomphrena globosa was a symptomless, systemic host; whereas $C$. quinoa and $C$. amaranticolor both developed chlorotic local lesions on inoculated leaves. All five of the Malvaceae species tested (okra, cotton, kenaf, Turk's cap, and hibiscus) developed symptomless, systemic infections under greenhouse conditions.

Purified IgG from rabbit polyclonal antiserum prepared to virions of the Florida hibiscus virus was used to develop a DASELISA for detection of the virus. Cuttings produced from virus-indexed hibiscus and testing negative by DAS-ELISA for Florida hibiscus virus were inoculated with virions. Replication and systemic movement of the virus was detected by DASELISA in the majority of these plants within a month after inoculation, although symptoms observed in landscape plantings were not reproduced under our greenhouse conditions in this same length of time. Infected hibiscus plants produced $A_{405} \mathrm{~nm}$ readings of 0.111 to 3.222 ; whereas uninfected hibiscus plants produced $A_{405} \mathrm{~nm}$ readings of 0.002 to 0.029 . No cross reaction with PMMoV virions was observed in DAS-ELISA.

Protein and RNA analysis. Florida hibiscus virus CP was analyzed by SDSPAGE of virion preparations (Fig. 3A, lane 2 ). The $C P$ migrated slightly slower than PMMoV CP and co-migrated with TMV CP (Fig. 3A, lanes 2 to 4), indicating that the Florida hibiscus virus $\mathrm{CP}$ is $\sim 17.5 \mathrm{kDa}$. No other proteins were observed, indicating that we had only isolated the putative tobamovirus from the infected hibiscus. Purified IgG from rabbit polyclonal antiserum prepared to virions of the Florida hibiscus virus reacted with $\mathrm{CP}$ in Western blots and was weakly cross-reactive with PMMoV and TMV CPs (Fig. 3B, lanes 1 to 3 ).

To determine if this putative tobamovirus was able to replicate in tobacco protoplasts, RNA was extracted from isolated virions and used to inoculate protoplasts derived from a tobacco suspension cell line (20). Total RNA was isolated from transfected protoplasts at $\sim 22 \mathrm{~h}$ postinoculation and analyzed by Northern blot hybridization with a probe complementary to an internal portion of the CP gene. The Florida hibiscus virus replicated in tobacco protoplasts despite an inability to systemically infect tobacco plants (Table 1). In addition to a genomic RNA of approximately $6.3 \mathrm{~kb}$, two subgenomic RNAs typically produced during tobamovirus replication accumulated to high levels (Fig. 3C). The larger and smaller subgenomic RNAs migrated to similar positions relative to TMV movement protein and CP subgenomic RNAs, respectively (data not shown).

CP sequence analysis. The nucleotide sequence of the putative Florida hibiscus 
virus $\mathrm{CP}$ gene was determined from several overlapping cDNA clones. The $\mathrm{CP}$ amino acid sequence was deduced from this sequence (GenBank accession no. AY250831). The CP gene encodes a protein of 158 amino acids with a predicted translation product of $\sim 17.5 \mathrm{kDa}$, consistent with the size estimate from SDSPAGE. The only sequences producing significant alignments from initial BLASTX and BLASTP queries were tobamovirus CPs, including many strains of some species. Later queries following publication of HVS sequence data (29) produced the most significant alignments with HVS. Florida hibiscus virus $\mathrm{CP}$ was aligned with the CPs of the 16 recognized tobamovirus species (18) for which CP sequence data are available and the recently reported HVS. Florida hibiscus virus and HVS $\mathrm{CP}$ genes share $68 \%$ nucleotide sequence identity, and the deduced CPs share $73 \%$ amino acid identity. However, the Florida hibiscus virus CP gene and deduced protein are only 45 to $53 \%$ and 37 to $47 \%$ identical at nucleotide and amino acid levels, respectively, to all other tobamoviruses.

Unlike our analyses, recent comparisons of tobamovirus CPs did not include Frangipani mosaic virus (FrMV) or all four species of cucurbit-infecting tobamoviruses $(3,11,16,29,38)$. In addition, we also included the putative tobamovirus, HVS, in our analyses (29). Trees based on multiple alignments of amino acid sequence (Fig. 4) had identical branching orders and similar bootstrap values throughout to trees based on nucleotide sequence (data not shown). In addition to the brassica-, solanaceous-, and cucurbit-infecting subgroups of tobamoviruses found in previous analyses $(11,16)$, Florida hibiscus virus and HVS always clustered in our analyses, whether neighbor-joining (Fig. 4) or maximum parsimony (data not shown) methods were used, suggesting the existence of a malvaceous-infecting subgroup of tobamoviruses.

Distribution of Florida hibiscus virus. Fifty-four hibiscus samples were collected from the Florida landscape in 14 towns in 11 different counties and analyzed for the putative tobamovirus by DAS-ELISA. Fifty-six percent of these samples, representing 12 towns in 10 counties scattered throughout peninsular Florida, were positive for the Florida hibiscus virus (Fig. 5). Both samples collected of a hibiscus relative, Turk's cap (Malvaviscus arboreus), also tested positive for the Florida hibiscus virus.

\section{DISCUSSION}

The Florida hibiscus virus appears to be a novel tobamovirus based on several criteria. The dsRNA profile and virion morphology (Fig. 2) are consistent with those of the tobamoviruses. Virions were successfully isolated from infected leaves by an established tobamovirus protocol and subsequently used to infect hibiscus plants. The $\mathrm{CP}$ is similar in size to those of PMMoV and TMV, and antiserum against it cross-reacts weakly with PMMoV and TMV CPs in Western blots (Fig. 3A and B), providing evidence for a distant relationship with these tobamoviruses. The viral RNAs produced during infection are of sizes typical of tobamoviruses with a

genomic RNA of $\sim 6.3 \mathrm{~kb}$ and two subgenomic RNAs (Fig. 3C). Tobamovirus and the putative tobamovirus, HVS, CPs were the only sequences producing significant alignments from BLAST queries with the deduced Florida hibiscus virus $\mathrm{CP}$ sequence.

Grouping viruses within the genus Tobamovirus based on sequence or host range

Table 1. Experimental host range and symptoms of Florida hibiscus virus

\begin{tabular}{|c|c|c|c|}
\hline Family $^{a}$ & Species & Common name & Symptoms $^{b}$ \\
\hline Amaranthaceae & Gomphrena globosa & Globe amaranth & NS/NS \\
\hline Apocynaceae & Adenium obesum & Desert rose & $-1-$ \\
\hline \multirow[t]{4}{*}{ Asteraceae } & Emilia sonchifolia & Red tassel flower & $-1-$ \\
\hline & Lactuca sativa cv. Burpee Bibb Butterhead & Lettuce & $-1-$ \\
\hline & Lactuca sativa cv. Parris Island Romaine & Lettuce & $-1-$ \\
\hline & Lactuca sativa $\mathrm{cv}$. Tiara & Lettuce & $-1-$ \\
\hline Balsaminaceae & Impatiens walleriana & Impatiens & $-1-$ \\
\hline \multirow[t]{6}{*}{ Brassicaceae } & Arabidopsis thaliana ecotype Columbia & Arabidopsis & $-1-$ \\
\hline & $\begin{array}{l}\text { Arabidopsis thaliana } \\
\text { ecotype Landsberg erecta }\end{array}$ & Arabidopsis & $-1-$ \\
\hline & Brassica oleracea cv. Brunswick & Cabbage & $-1-$ \\
\hline & Brassica oleracea cv. Copenhagen Market & Cabbage & $-1-$ \\
\hline & Brassica oleracea cv. Vates & Collards & $-1-$ \\
\hline & Brassica rapa cv. White Egg & Turnip & $-1-$ \\
\hline Caryophyllaceae & Dianthus chinensis cv. Spring Beauty & Dianthus & $-1-$ \\
\hline \multirow[t]{2}{*}{ Chenopodiaceae } & Chenopodium amaranticolor & Lambsquarters & CLL/- \\
\hline & Chenopodium quinoa & Lambsquarters & CLL/- \\
\hline Convolvulaceae & Ipomoea alba & Moonflower & $-1-$ \\
\hline \multirow{3}{*}{ Cucurbitaceae } & Citrullus lanatus cv. Crimson Sweet & Watermelon & $-1-$ \\
\hline & Cucumis sativus cv. Burpee Straight 8 & Cucumber & $-1-$ \\
\hline & Cucurbita pepo cv. Burpee zucchini hybrid & Squash & $-1-$ \\
\hline \multirow[t]{2}{*}{ Fabaceae } & Crotalaria juncea & Sunn hemp & $-1-$ \\
\hline & Phaseolus vulgaris & Pinto bean & $-1-$ \\
\hline Lamiaceae & Ocimum basilicum & Basil & $-1-$ \\
\hline Liliaceae & Amaryllis belladonna & Amaryllis & $-1-$ \\
\hline \multirow[t]{6}{*}{ Malvaceae } & $\begin{array}{l}\text { Abelmoschus esculentus } \\
\text { cv. Clemson Spineless }\end{array}$ & Okra & NS/NS \\
\hline & $\begin{array}{l}\text { Abelmoschus esculentus } \\
\text { cv. North and South hybrid }\end{array}$ & Okra & NS/NS \\
\hline & Gossypium hirsutum cv. DES 607 & Cotton & NS/NS \\
\hline & Hibiscus cannabinus & Kenaf & NS/NS \\
\hline & Hibiscus rosa-sinensis & Hibiscus & NS/NS \\
\hline & Malvaviscus arboreus & Turk's cap & NS/NS \\
\hline Nyctaginaceae & Mirabilis jalapa & Four o'clock & $-1-$ \\
\hline \multirow[t]{19}{*}{ Solanaceae } & Capsicum аппиит cv. Enterprise & Bell pepper & $-1-$ \\
\hline & Datura metel & Downy thorn apple & $-1-$ \\
\hline & Datura stramonium & Jimsonweed & $-1-$ \\
\hline & Lycopersicon esculentum cv. Bonnie Best & Tomato & $-1-$ \\
\hline & Nicotiana benthamiana & & NS/NS \\
\hline & Nicotiana debneyi & & $\mathrm{NS} /-^{\mathrm{c}}$ \\
\hline & Nicotiana excelsior & & $\mathrm{NS} / \_^{\mathrm{c}}$ \\
\hline & Nicotiana glutinosa & & NLL,RS/- \\
\hline & Nicotiana megalosiphon & & $-1-$ \\
\hline & Nicotiana occidentalis & & $\mathrm{NS} /-^{\mathrm{c}}$ \\
\hline & Nicotiana rustica & & CLL/- \\
\hline & Nicotiana sylvestris & & $-1-$ \\
\hline & Nicotiana tabacum cv. Xanthi & Tobacco & $-1-$ \\
\hline & Nicotiana tabacum cv. Xanthi nc & Tobacco & $-1-$ \\
\hline & Petunia $\times$ hybrida & Petunia & NLL/- \\
\hline & Physalis alkekengi & Chinese lantern & $-1-$ \\
\hline & Solanum americanum & $\begin{array}{l}\text { American black } \\
\text { nightshade }\end{array}$ & $-1-$ \\
\hline & Solanum bahamense & $\begin{array}{l}\text { Key West } \\
\text { nightshade }\end{array}$ & $-1-$ \\
\hline & Solanum melongena cv. Black Beauty & Eggplant & $-1-$ \\
\hline Tropaeolaceae & Tropaeolum majus & Nasturtium & $-1-$ \\
\hline
\end{tabular}

a Family and species names according to Brako et al. (5) and USDA, NRCS (33).

b Symptoms on inoculated leaves and upper uninoculated leaves indicated to left and right of slash, respectively. $-=$ no infection, $\mathrm{NS}=$ infected but no symptoms, $\mathrm{NLL}=$ necrotic local lesions, $\mathrm{CLL}=$ chlorotic local lesions, RS = ringspots. Systemic infection confirmed by inoculation of Chenopodium quinoa with upper, uninoculated leaves homogenized in $20 \mathrm{mM}$ sodium phosphate buffer ( $\mathrm{pH} 7.0)$ containing $1 \%(\mathrm{wt} / \mathrm{vol})$ Celite.

${ }^{\mathrm{c}}$ Local infection confirmed by inoculation of $C$. quinoa with washed, inoculated leaves as above. 
produces similar results $(3,11,16,38)$. We have aligned Florida hibiscus virus CP with $\mathrm{CP}$ sequences of recognized tobamovirus species (18) and the recently reported HVS (29). The three previously proposed subgroups of tobamoviruses are those that infect (i) solanaceous plants, (ii) brassicas, or (iii) cucurbits or legumes $(11,16)$. Due to recently published sequences, this is the first tobamovirus $\mathrm{CP}$ comparison to include two malvaceousinfecting putative tobamoviruses (Florida hibiscus virus and HVS) and an apocynaceous-infecting tobamovirus (FrMV). The report by Srinivasan et al. (29) indicated that HVS is distinct from all recognized tobamoviruses. Our comparison of $\mathrm{CP}$ sequences shows that Florida hibiscus virus is also different from all recognized tobamovirus species and from HVS, indicating that Florida hibiscus virus and HVS should be considered distinct tobamoviruses.

Within the genus Tobamovirus, CPs share 30 to $92 \%$ amino acid identity, and CP genes share 41 to $89 \%$ nucleotide identity. Based upon $\mathrm{CP}$ sequence, Florida hibiscus virus is most similar to HVS, sharing 73 and $68 \%$ amino acid and nucleotide identity, respectively. Although Florida hibiscus virus and HVS CPs are more similar to one another than to any other tobamovirus $\mathrm{CP}$, the levels of sequence identity are lower than those of some tobamoviruses recognized as distinct species (e.g., TMV and Tomato mosaic virus). Florida hibiscus virus shares 37 to $47 \%$ amino acid identity and 45 to $53 \%$ nucleotide identity with the $\mathrm{CPs}$ and $\mathrm{CP}$ genes of recognized tobamovirus species, respectively. Similar degrees of amino acid and nucleotide identity occur between the CPs and CP genes of Sunn-hemp mosaic virus (SHMV), FrMV, and HVS and all other recognized tobamovirus species. Neither of the hibiscus viruses' nor SHMV and FrMV CPs clustered with the three major tobamovirus subgroups (Fig. 4). We note that these four viruses were isolated from hosts belonging to different plant families than those from which the tobamoviruses comprising the three major subgroups were isolated. Florida hibiscus virus and HVS always clustered in our analyses, suggesting that a malvaceousinfecting subgroup of tobamoviruses exists.

Malvaceous plants have not been reported as hosts for any of the recognized tobamoviruses $(6,8,9)$, although a single, brief report from Japan documents a putative tobamovirus isolated from hibiscus in that country (14), and a recent report documents the putative tobamovirus HVS from hibiscus in Singapore (29). Based on their malvaceous host range, Florida hibiscus virus and HVS are distinct from all recognized tobamovirus species. We inoculated hibiscus, okra, cotton, and kenaf with TMV and PMMoV virions and confirmed that they are not systemic hosts for these tobamoviruses (data not shown), further substantiating the uniqueness of the host range of the Florida hibiscus virus and suggesting that it is a novel tobamovirus. These results are also consistent with Gibbs' (11) theory that individual tobamoviruses are adapted to specific plant families to facilitate virus survival.

The most common viruslike symptoms observed in Florida hibiscus are diffuse chlorotic spots and rings and an overall

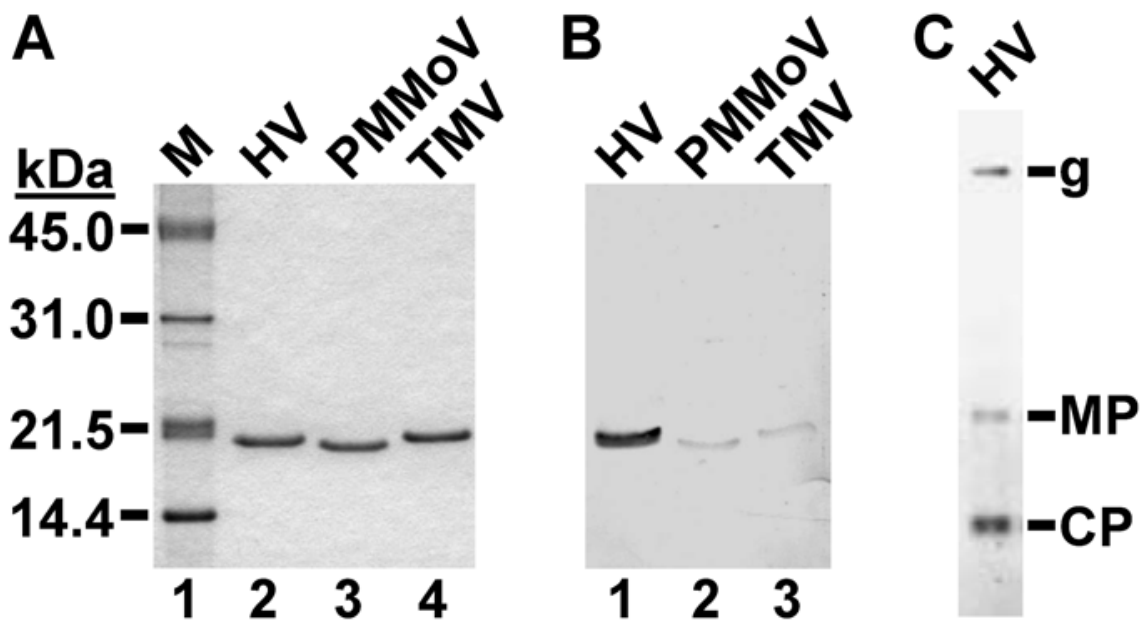

Fig. 3. Characterization of Florida hibiscus virus (HV) coat protein (CP) and RNA provides evidence of a typical tobamovirus genome organization. A, CP is similar in size to Pepper mild mottle virus (PMMoV) and Tobacco mosaic virus (TMV) CPs. Aliquots of virion preparations (1,000 ng each) were analyzed by denaturing electrophoresis on a $15 \%$ sodium dodecyl sulfate-polyacrylamide gel and stained with Coomassie brilliant blue (lanes 2 to 4). The positions of pre-stained molecular weight markers (lane 1) are indicated to the left of the gel (in $\mathrm{kDa}$ ). $\mathbf{B}$, Western blot of a replicate gel to that shown in (A) was probed with IgG against HV. C, Northern blot of total RNA extracted from tobacco protoplasts at $\sim 22 \mathrm{~h}$ postinoculation with HV virion RNA and probed with the complement of an internal portion of the CP gene. Positions of the HV genomic (g), movement protein (MP) and $\mathrm{CP}$ subgenomic RNAs are indicated. chlorotic mottle (Fig. 1A and B). After isolation and characterization of the putative tobamovirus, we used DAS-ELISA to re-examine the original symptomatic hibiscus plants. We detected the putative tobamovirus using the $\mathrm{IgG}$ prepared in this report. No cross reaction of this $\operatorname{IgG}$ with hibiscus proteins or PMMoV virions was observed in DAS-ELISA. We also detected HCRSV using commercially available diagnostic reagents (Agdia, Elkhart, IN). Because HCRSV is reported to cause similar symptoms in hibiscus, including chlorotic spots, rings, and vein-banding (35), we made an effort to address whether the Florida hibiscus virus or HCRSV was inducing these symptoms in the original plants. Chlorotic spots and rings and areas of chlorotic mottle were cut in half, and one half was assayed for each virus. The Florida hibiscus virus was usually only detected in areas of chlorotic mottle, whereas HCRSV was predominantly associated with chlorotic spots and rings (data not shown).

The report from Japan indicates that the hibiscus plant from which the putative tobamovirus was isolated was also infected with HCRSV (14). Kashiwazaki and colleagues (14) proposed the name Hibiscus yellow mosaic virus for their putative tobamovirus, and an entry under this name is found in the VIDE database $(6,8,9)$. Might the Florida hibiscus virus be the same virus reported in hibiscus from Japan (14) that also induced local lesions on C. quinoa and Petunia $\times$ hybrida? Although this is consistent with our current results with the Florida hibiscus virus, it alone is insufficient to conclude that these are the same virus. However, based on our results, it is conceivable that the symptoms leading to the proposed Hibiscus yellow mosaic virus name were partly or wholly induced by HCRSV. Our inoculation experiments show that the Florida hibiscus virus can cause symptomless infections in hibiscus and other malvaceous plants under greenhouse conditions. Symptoms may only appear when the plant is stressed, perhaps by infection with a second virus such as HCRSV. Symptoms also may vary with the hibiscus cultivar and/or species and environmental conditions. This may explain why little information about putative hibiscus tobamoviruses has been forthcoming, although this may also be due to the inherent difficulties of working with a woody perennial plant.

The recent report from Singapore does not indicate what symptoms, if any, were observed on the hibiscus plant from which HVS was isolated (29). Inoculation of only three indicator hosts (kenaf, $N$. benthamiana, and C. quinoa) was reported for HVS. The symptomless, systemic infection of kenaf is identical to our current observations with the Florida hibiscus virus, as is the systemic infection of $N$. benthamiana, although no mention of symptoms, if any, 
was made (Table $1 ; 29)$. From the currently available information, $C$. quinoa may be a potential differential host for the Florida hibiscus virus and HVS, since we routinely observed chlorotic local lesions, whereas Srinivasan and colleagues (29) reported necrotic local lesions for HVS.

It is not clear why only the Florida hibiscus virus was successfully transmitted mechanically from the original hibiscus plants to $C$. quinoa, because HCRSV is also reported to induce chlorotic local lesions in $C$. quinoa (35). However, several lines of evidence make it very clear that only the putative tobamovirus was transmitted and subsequently isolated: (i) only tobamovirus dsRNA was isolated from inoculated C. quinoa (Fig. 2A); (ii) only rod-shaped particles were observed in our virion preparations (Fig. 2B); (iii) only one protein was detected in virion preparations, and it was similar in size to tobamovirus
CPs (HCRSV CP is reported to be $\sim 38$ $\mathrm{kDa}$, roughly twice the size of tobamovirus CPs [12]; note the absence of any proteins in this region in Fig. 3A); (iv) the putative tobamovirus induced no symptoms on kenaf, cotton, and pinto bean (Table 1), all of which are a local-lesion host and/or systemic host (kenaf) for HCRSV (35); and (v) our preparations of the putative tobamovirus did not react with HCRSV antiserum (data not shown).

Our initial survey shows that the Florida hibiscus virus is widely distributed in peninsular Florida in hibiscus and related plants. The geographic distribution of putative tobamoviruses infecting hibiscus now includes two continents. Whether the virus characterized in this manuscript is present in Southeast Asia remains to be determined. Additional research, especially coinoculation experiments with HCRSV, is necessary to determine whether symptoms

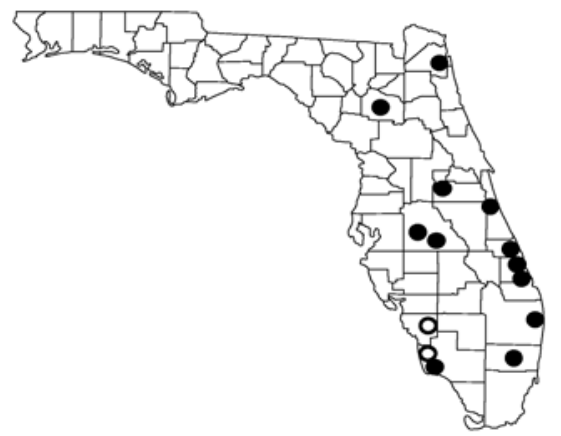

Fig. 5. Distribution of Florida hibiscus virus in peninsular Florida. Map shows Florida counties with 14 towns (indicated with circles) from which 54 hibiscus plants were sampled. Filled circles indicate the presence of at least one infected hibiscus plant as determined by double antibody sandwich enzyme-linked immunosorbent assay.

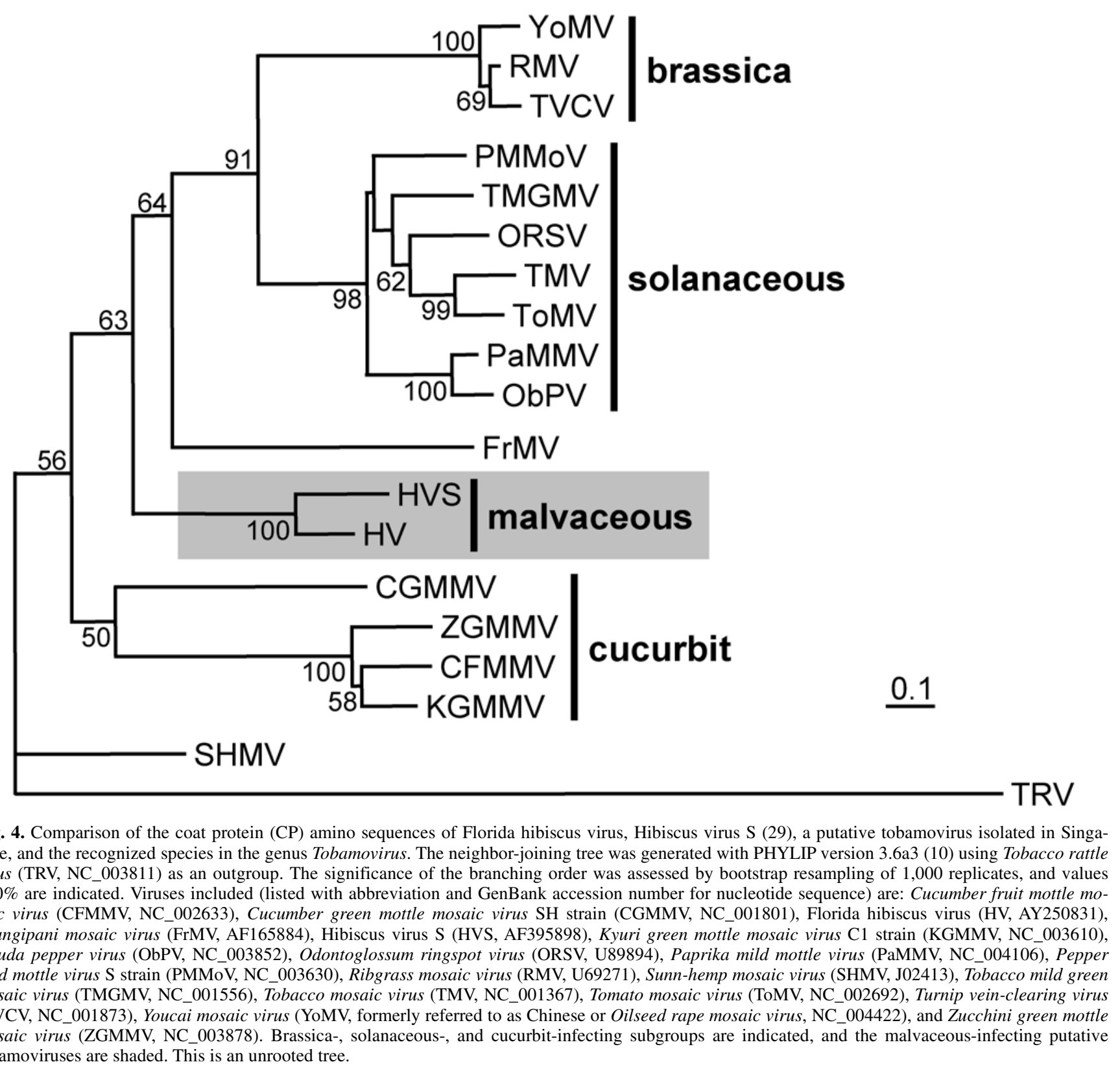


are induced in hibiscus by the Florida hibiscus virus alone or in concert with HCRSV before a definitive, symptombased name can be proposed for this putative tobamovirus.

\section{ACKNOWLEDGMENTS}

We thank Carrie Vanderspool, Karen Cerveny, Heather Capobianco, Reid Lewis, and Gregory Danyluk for excellent technical assistance, Erin Rosskopf, Betsy Lamb, Dan Chellemi, Rick Nelson, and Thomas Abbott for providing seed, Brad Reddick and Nancy Rechcigl for providing culture virus-indexed hibiscus cuttings, and Mark Hilf and María A. Ayllón for valuable discussions.

\section{LITERATURE CITED}

1. Adkins, S., Lamb, E. M., Roberts, P. D., Gooch, M. D., Breman, L., and Shuler, K. D. 2001. Identification of Pepper mild mottle virus in commercial bell pepper in Florida. Plant Dis. 85:679.

2. Altschul, S. F., Madden, T. L., Schäffer, A. A., Zhang, J., Zhang, Z., Miller, W., and Lipman, D. J. 1997. Gapped BLAST and PSI-BLAST: A new generation of protein database search programs. Nucleic Acids Res. 25:3389-3402.

3. Antignus, Y., Wang, Y., Pearlsman, M., Lachman, O., Lavi, N., and Gal-On, A. 2001. Biological and molecular characterization of a new cucurbit-infecting tobamovirus. Phytopathology 91:565-571.

4. Avrameas, S. 1969. Coupling of enzyme to proteins with glutaraldehyde. Immunochemistry 6:43-52.

5. Brako, L., Rossman, A. Y., and Farr, D. F. 1995. Scientific and Common Names of 7,000 Vascular Plants in the United States. American Phytopathological Society, St. Paul, MN.

6. Brunt, A. A., Crabtree, K., Dallwitz, M., Gibbs, A., and Watson, L. 1996. Viruses of Plants: Descriptions and Lists from the VIDE Database. C.A.B. International, UK.

7. Clark, M. F., and Adams, A. N. 1977. Characterization of the microplate method of enzyme-linked immunosorbent assay for the detection of plant viruses. J. Gen. Virol. 34:475483.

8. Dallwitz, M. J. 1980. A general system for coding taxonomic descriptions. Taxon 29:4146.

9. Dallwitz, M. J., Paine, T. A., and Zurcher, E. J. 1993. User's Guide to the DELTA System: A general system for processing taxonomic descriptions. 4th ed. CSIRO Division of Entomology, Canberra.

10. Felsenstein, J. 1989. PHYLIP - Phylogeny Inference Package. Version 3.2. Cladistics 5:64-166.

11. Gibbs, A. 1999. Evolution and origins of tobamoviruses. Phil. Trans. R. Soc. Lond. B 354:593-602.
12. Huang, M., Koh, D. C., Weng, L., Chang, M., Yap, Y., Zhang, L., and Wong, S. 2000. Complete nucleotide sequence and genome organization of hibiscus chlorotic ringspot virus, a new member of the genus carmovirus: Evidence for the presence and expression of two novel open reading frames. J. Virol. 74:3149-3155.

13. Hull, R. 2002. Matthews' Plant Virology. 4th ed. Academic Press, San Diego.

14. Kashiwazaki, T., Yamashita, S., and Doi, Y. 1982. Ann. Phytopathol. Soc. Jpn. 48:395.

15. Lana, A. O. 1974. A new ringspot virus disease in hibiscus rosa-sinensis. Plant Dis. Rep. 58:1040-1042.

16. Lartey, R. T., Voss, T. C., and Melcher, U. 1996. Tobamovirus evolution: Gene overlaps, recombination, and taxonomic implications. Mol. Biol. Evol. 13:1327-1338.

17. Lawson, R. H. 1995. Virus and Virus-like Diseases of Bulb and Flower Crops. G. Loebenstein, R. H. Lawson, and A. A. Brunt, eds. John Wiley \& Sons, Chichester. pp. 476-481.

18. Lewandowski, D. J. 2000. Virus Taxonomy Classification and Nomenclature of Viruses, 7th Report of the ICTV. M. H. V. van Regenmortel, C. M. Fauquet, D. H. L. Bishop, E. B. Carstens, M. K. Estes, S. M. Lemon, J. Maniloff, M. A. Mayo, D. J. McGeoch, C. R. Pringle, and R. B. Wickner, eds. Academic Press, San Diego. pp. 889-894.

19. Lewandowski, D. J., and Dawson, W. O. 1998. Deletion of internal sequences results in tobacco mosaic virus defective RNAs that accumulate to high levels without interfering with replication of the helper virus. Virology 251:427-437.

20. Lewandowski, D. J., and Dawson, W. O. 2000. Functions of the 126- and 183-kDa proteins of tobacco mosaic virus. Virology 271:90-98

21. Lockhart, B. E. L. 1987. Evidence for identity of plant rhabdoviruses causing veinyellowing diseases of tomato and Hibiscus rosa-sinensis. Plant Dis. 71:731-733.

22. Navas-Castillo, J., Albiach-Martí, M. R., Gowda, S., Hilf, M. E., Garnsey, S. M., and Dawson, W. O. 1997. Kinetics of accumulation of citrus tristeza virus RNAs. Virology 228:92-97.

23. Nicholas, K. B., and Nicholas, H. B., Jr. 1997. GeneDoc: A tool for editing and annotating multiple sequence alignments. Pittsburgh Supercomputing Center, Pittsburgh, PA.

24. Oglevee-O'Donovan, W. 1986. Tissue Culture as a Plant Production System for Horticultural Crops. R. H. Zimmerman, R. J. Griesbach, F. A. Hammerschlag, and R. H. Lawson, eds. Martinus Nijhoff Publishers, Dordrecht, Netherlands. pp. 119-123.

25. Page, R. D. M. 1996. TREEVIEW: An application to display phylogenetic trees on personal computers. Computer Applic.
Biosci. 12:357-358

26. Ryu, K. H., Min, B. E., Choi, G. S., Choi, S. H., Kwon, S. B., Noh, G. M., Yoon, J. Y., Choi, Y. M., Jang, S. H., Lee, G. P., Cho, K. H., and Park, W. M. 2000. Zucchini green mottle mosaic virus is a new tobamovirus; comparison of its coat protein gene with that of kyuri green mottle mosaic virus. Arch. Virol. 145:2325-2333.

27. Sambrook, J., and Russell, D. W. 2001. Molecular Cloning: A Laboratory Manual. 3rd ed. Cold Spring Harbor Laboratory, Cold Spring Harbor, NY

28. Scholthof, K.-B. G., Shaw, J. G., and Zaitlin, M., eds. 1999. Tobacco Mosaic Virus: One Hundred Years of Contributions to Virology. American Phytopathological Society, St. Paul, MN.

29. Srinivasan, K. G., Narendrakumar, R., and Wong, S. M. 2002. Hibiscus virus $S$ is a new subgroup II tobamovirus: Evidence from its unique coat protein and movement protein sequences. Arch. Virol. 147:1585-1598.

30. Thompson, J. D., Gibson, T. J., Plewniak, F. Jeanmougin, F., and Higgins, D. G. 1997. The ClustalX Windows interface: Flexible strategies for multiple sequence alignment aided by quality analysis tools. Nucleic Acids Res. 24:4876-4882.

31. Thompson, J. D., Higgins, D. G., and Gibson, T. J. 1994. CLUSTAL W: Improving the sensitivity of progressive multiple sequence alignment through sequence weighting, position-specific gap penalties and weight matrix choice. Nucleic Acids Res. 22:4673-4680.

32. Ullman, D. E., German, T. L., Sherwood, J. L., Westcot, D. M., and Cantone, F. A. 1993. Tospovirus replication in insect vector cells: Immunocytochemical evidence that the nonstructural protein encoded by the S RNA of Tomato spotted wilt tospovirus is present in thrips vector cells. Phytopathology 83:456463.

33. U.S. Dep. Agric., NRCS. 2001. The PLANTS Database, Version 3.1. National Plant Data Center, Baton Rouge, LA. Published online.

34. Valverde, R. A., Nameth, S. T., and Jordan, R L. 1990. Analysis of double-stranded RNA for plant virus diagnosis. Plant Dis. 74:255-258

35. Waterworth, H. 1980. Hibiscus chlorotic ringspot virus. $\mathrm{CMI} / \mathrm{AAB}$ Descriptions of Plant Viruses No. 227.

36. Wetter, C., and Conti, M. 1988. Pepper mild mottle virus. CMI/AAB Descriptions of Plant Viruses No. 330.

37. Wolfswinkel, L. D. 1966. A virus disease in hibiscus rosa-sinensis L. S. Afr. J. Agric. Sci. 9:483-486.

38. Yoon, J. Y., Min, B. E., Choi, J. K., and Ryu, K. H. 2002. Genome structure and production of biologically active in vitro transcripts of cucurbit-infecting Zucchini green mottle mosaic virus. Phytopathology 92:156-163. 